\title{
Oxidation Behavior Comparison of UAM and Conventional Zry-4
}

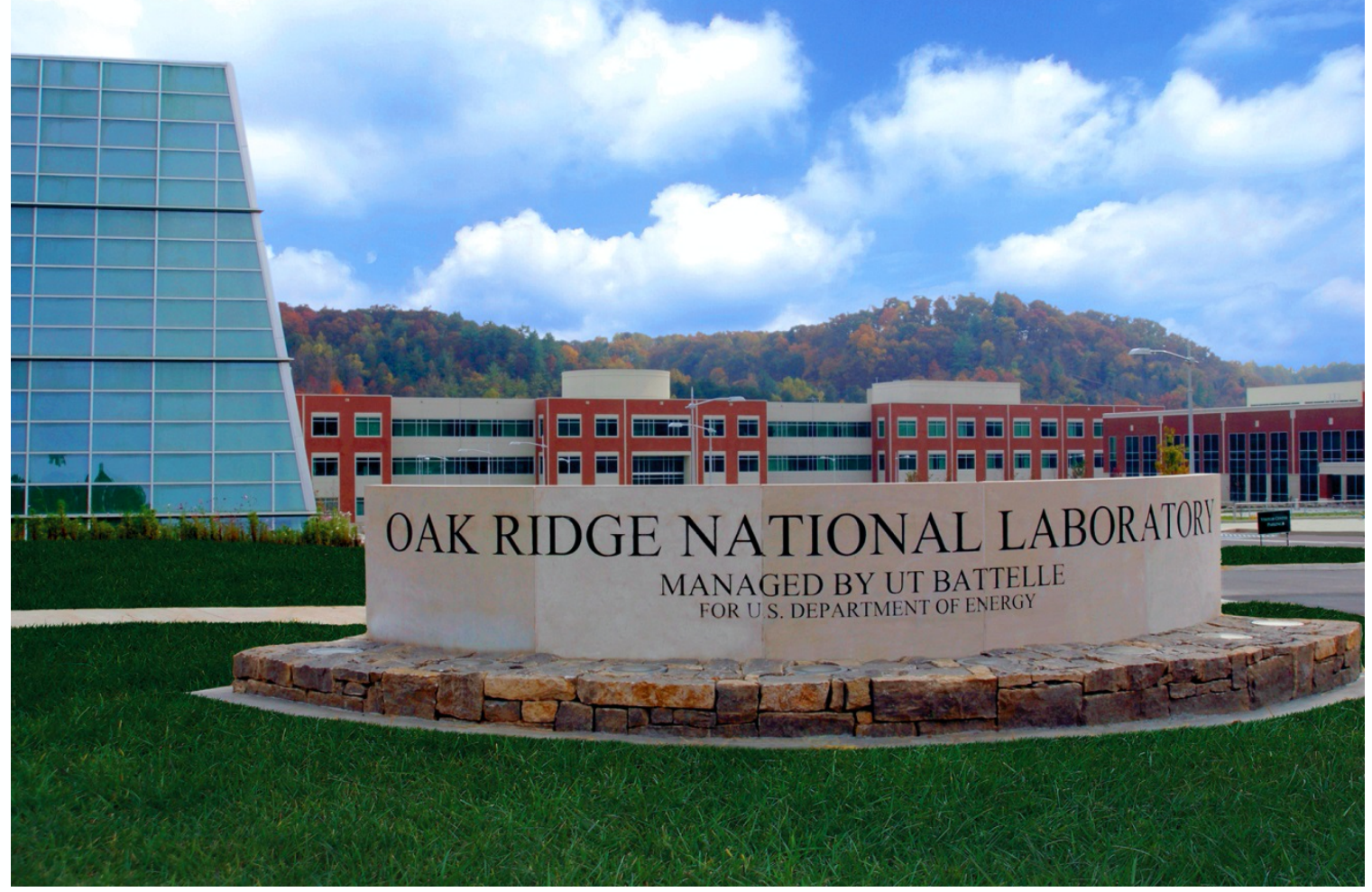

Cory G. Parker

Ken A. Kane

Caleb P. Massey

Andrew T. Nelson

Bruce A. Pint

September 2021 


\title{
DOCUMENT AVAILABILITY
}

Reports produced after January 1, 1996, are generally available free via US Department of Energy (DOE) SciTech Connect.

Website www.osti.gov

Reports produced before January 1, 1996, may be purchased by members of the public from the following source:

\author{
National Technical Information Service \\ 5285 Port Royal Road \\ Springfield, VA 22161 \\ Telephone 703-605-6000 (1-800-553-6847) \\ TDD 703-487-4639 \\ Fax 703-605-6900 \\ E-mail info@ntis.gov \\ Website http://classic.ntis.gov/
}

Reports are available to DOE employees, DOE contractors, Energy Technology Data Exchange representatives, and International Nuclear Information System representatives from the following source:

Office of Scientific and Technical Information

PO Box 62

Oak Ridge, TN 37831

Telephone 865-576-8401

Fax 865-576-5728

E-mail reports@osti.gov

Website https://www.osti.gov/

This report was prepared as an account of work sponsored by an agency of the United States Government. Neither the United States Government nor any agency thereof, nor any of their employees, makes any warranty, express or implied, or assumes any legal liability or responsibility for the accuracy, completeness, or usefulness of any information, apparatus, product, or process disclosed, or represents that its use would not infringe privately owned rights. Reference herein to any specific commercial product, process, or service by trade name, trademark, manufacturer, or otherwise, does not necessarily constitute or imply its endorsement, recommendation, or favoring by the United States Government or any agency thereof. The views and opinions of authors expressed herein do not necessarily state or reflect those of the United States Government or any agency thereof. 
Materials Science and Technology Division

\title{
OXIDATION BEHAVIOR COMPARISON OF UAM AND CONVENTIONAL ZRY-4
}

\author{
Cory G. Parker \\ Ken A. Kane \\ Bruce A. Pint \\ Materials Science and Technology Division \\ Oak Ridge National Laboratory \\ Caleb P. Massey \\ Andrew T. Nelson \\ Nuclear Energy and Fuel Cycle Division \\ Oak Ridge National Laboratory
}

September 2021

Prepared by

OAK RIDGE NATIONAL LABORATORY

Oak Ridge, TN 37831-6283

managed by

UT-BATTELLE LLC

for the

US DEPARTMENT OF ENERGY

under contract DE-AC05-00OR22725 



\section{CONTENTS}

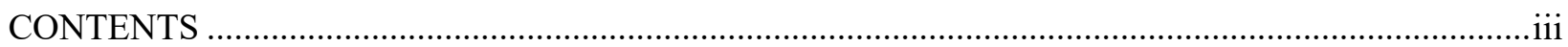

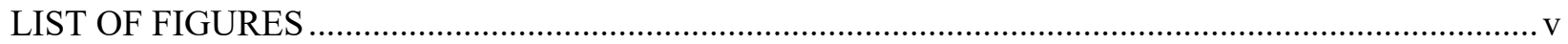

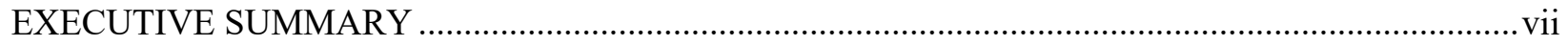

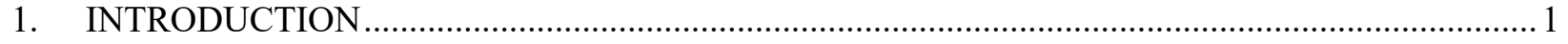

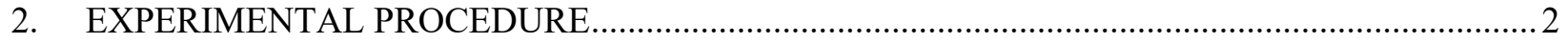

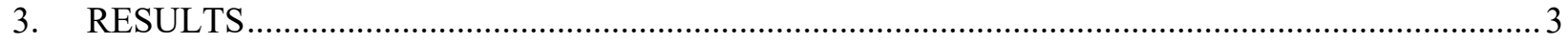

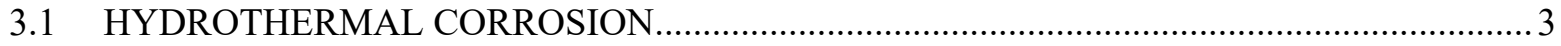

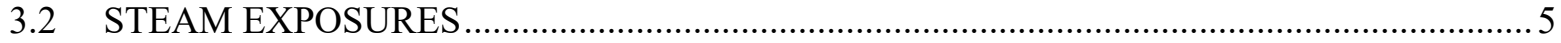

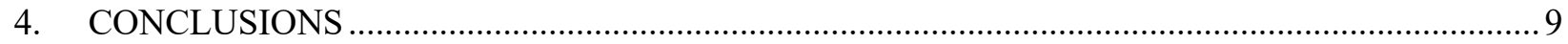

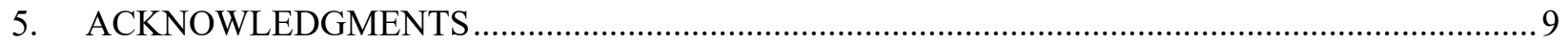

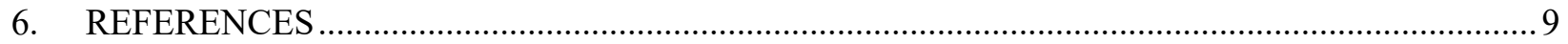





\section{LIST OF FIGURES}

Figure 1. Schematic of UAM process.

Figure 2. Mass change data for UAM and wrought Zry-4 tested in a continuously refreshing autoclave at $330^{\circ} \mathrm{C}, 15 \mathrm{MPa},<50 \mathrm{ppb}$ oxygen, for $500 \mathrm{~h}$.

Figure 3. Optical images of representative samples from hydrothermal corrosion tests, exposed at $330^{\circ} \mathrm{C}, 15 \mathrm{MPa},<50 \mathrm{ppb}$ oxygen, for $500 \mathrm{~h}$.

Figure 4. BSE SEM images of a UAM specimen after exposure in PWR conditions for $500 \mathrm{~h}$ at $330^{\circ} \mathrm{C}$

Figure 5. BSE SEM images of Zry-4 specimens after exposure in PWR conditions for $500 \mathrm{~h}$ at $330^{\circ} \mathrm{C}$, (a) UAM and (b) wrought

Figure 6. Oxide thickness measurements of each UAM and wrought Zry-4 samples tested in a continuously refreshing autoclave at $330^{\circ} \mathrm{C}, 15 \mathrm{MPa},<50 \mathrm{ppb}$ oxygen, for $500 \mathrm{~h}$.

Figure 7. Specific mass change TGA data for UAM and wrought Zry-4 tested in $100 \% \mathrm{H}_{2} \mathrm{O}(\mathrm{g})$ for $1 \mathrm{~h}$ at $700^{\circ} \mathrm{C}$.

Figure 8. BSE SEM image of interlayer oxidation of a UAM Zry-4 sample tested in $100 \% \mathrm{H}_{2} \mathrm{O}(\mathrm{g})$ at $700^{\circ} \mathrm{C}$ for $1 \mathrm{~h}$.

Figure 9. Oxide thickness measurements of the external oxide of UAM and wrought Zry-4 tested in $100 \% \mathrm{H}_{2} \mathrm{O}(\mathrm{g})$ at $700^{\circ} \mathrm{C}$ for $1 \mathrm{~h}$.

Figure 10. Specific mass change vs. time for UAM and wrought Zry-4 tested in $100 \% \mathrm{H}_{2} \mathrm{O}$ at $900^{\circ} \mathrm{C}$ for $1 \mathrm{~h}$.

Figure 11. BES SEM images of Zry-4 after $1 \mathrm{~h}$ in steam at $900^{\circ} \mathrm{C}$, (a) UAM and (b) wrought.

Figure 12. Oxide thickness measurements for UAM and wrought Zry-4 tested in $100 \% \mathrm{H}_{2} \mathrm{O}$ at $900^{\circ} \mathrm{C}$ for $1 \mathrm{~h}$.

Figure 13. Mass change for UAM and wrought Zry-4 samples tested in $100 \% \mathrm{H}_{2} \mathrm{O}(\mathrm{g})$ at $1100^{\circ} \mathrm{C}$ for $10 \mathrm{~min}$.

Figure 14. BSE SEM images of Zry-4 specimens (a) UAM and wrought Zry-4 samples exposed to $100 \% \mathrm{H}_{2} \mathrm{O}(\mathrm{g})$ at $1100^{\circ} \mathrm{C}$ for $10 \mathrm{~min}$. 



\section{EXECUTIVE SUMMARY}

Initial hydrothermal corrosion and steam exposures have been completed on ultrasonic additive manufacturing (UAM) Zry4 specimens to compare to wrought Zry4 performance in both normal operation and accident conditions. Slightly higher mass gains were found for the UAM Zry4 specimens in both conditions, but these were generally associated with internal oxidation where delamination of build layers occurred in the UAM material. Further characterization is being completed to conclude this first phase of testing while a second phase is being planned. 



\section{INTRODUCTION}

Zircaloy-4 (Zry-4) is a material used in light water reactors (LWRs), particularly for fuel cladding, due to its small neutron capture cross section and acceptable behavior in LWR environments [1-3]. While most current fuel cladding is tubular in shape, new manufacturing methods may enable new innovative designs [4]. The ultrasonic additive manufacturing (UAM) technique is one possible path to manufacturing cladding [4-7] while including a complex heterogeneous internal architecture as has been demonstrated previously for aluminum alloy prototypes [8]. This solid state joining process has primarily been demonstrated on aluminum and copper metals and alloys, and not until recently on zirconium alloys [4].

UAM is a solid state joining technique whereby $50-250 \mu \mathrm{m}$ layers of material are joined together sequentially in layers using ultrasonic mechanical energy. A schematic of this process is shown in Figure 1. A sonotrode is powered in three directions: force applied normal to the build direction $(\mathrm{Z})$, sonic vibrations applied to the sonotrode $(\mathrm{Y})$, and rolling forward along the length of the tape material $(\mathrm{X})$. Copper and aluminum were initially explored using UAM because of their high ductility [5-6]. More complex structures also have been explored, for example, using Ni interlayers to fabricate austenitic steel alloys [7]. A lack of voids between layers is important to ensure the total mechanical energy output by the sonotrode is put into the built material, rather than lost in elastic deformation of the layer below.

Zirconium-based alloys are HCP structured, and so ductility and machinability are not as ideal for the UAM process as are FCC alloys. Initial UAM Zircaloy-4 (Zry-4) results were recently published [4]. The grain structure of the built material showed large amounts of texturing, with cracking and layer separation being a common issue. The cracking present in as-built UAM Zry-4 material raised a concern about the oxidation resistance of this material. This study provides some preliminary results comparing the oxidation behavior of conventional wrought Zry-4 and UAM Zry-4 in pressurized water reactor (PWR) operating conditions at $330^{\circ} \mathrm{C}$ and in accident scenarios with steam oxidation [9-11] exposures at $700^{\circ}$ $1100^{\circ} \mathrm{C}$.

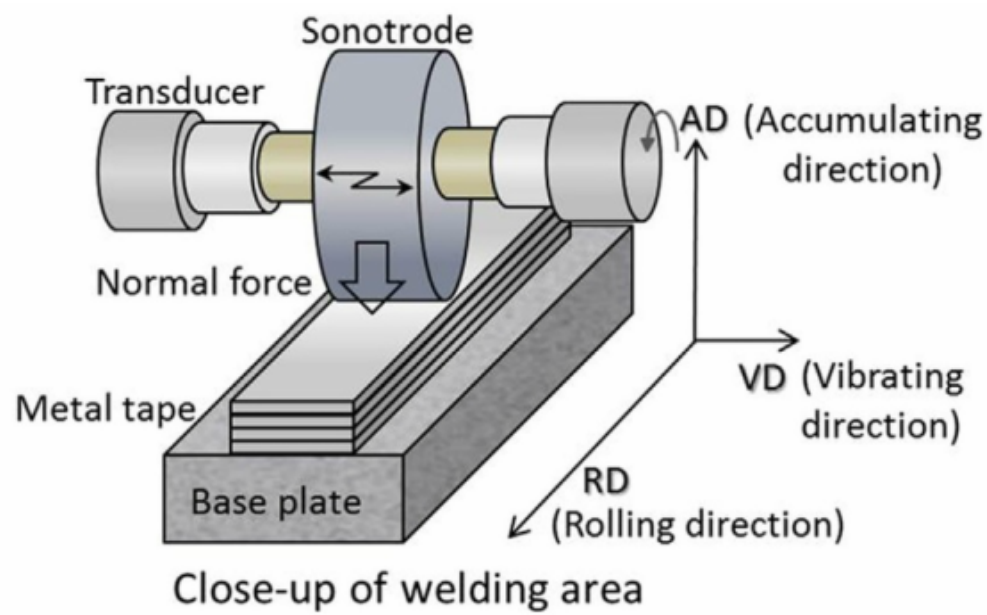

Figure 1. Schematic of UAM process. 


\section{EXPERIMENTAL PROCEDURE}

UAM material was built on a cast Zry-4 baseplate. Seven $\sim 150 \mu \mathrm{m}$ thick layers were used in the build. The Zry-4 baseplate was removed from the UAM material using electrical discharge machining (EDM), leaving samples $\sim 1 \mathrm{~mm}$ in thickness. Samples of both wrought Zry-4 and UAM had dimensions of $\sim 1 \mathrm{x}$ $12 \times 20 \mathrm{~mm}$ and were polished to a 1200 grit $\mathrm{SiC}$ finish, attempting to remove as little material as possible from the UAM specimens.

Two sets of experiments were carried out to test oxidation behavior in conditions simulating typical PWR operation and accident conditions. The first was a hydrothermal corrosion test in a continuously refreshing autoclave with laminar flow at $330^{\circ} \mathrm{C}, 15 \mathrm{MPa}$, and with oxygen content $<50 \mathrm{ppb}$, for $500 \mathrm{~h}$. Samples were hung on Dura-Z MgO partially stabilized zirconia rods (Coorstek, Golden, CO). A $103 \mathrm{kPa}$ pressure of $\mathrm{H}_{2}(\mathrm{~g})$ was maintained above the water column in the loop to reduce oxygen content in the water throughout the test.

To simulate accident conditions, $100 \% \mathrm{H}_{2} \mathrm{O}(\mathrm{g})$ exposures in a Rubotherm thermogravimetric analysis (TGA) furnace were done at $700^{\circ} \mathrm{C}$ for $1 \mathrm{~h}, 900^{\circ} \mathrm{C}$ for $1 \mathrm{~h}$, and $1100^{\circ} \mathrm{C}$ for $10 \mathrm{~min}$. To prevent condensation, steam was introduced during heating at $600^{\circ} \mathrm{C}$ for all TGA experiments. Sample mass was measured before and after exposure. After exposure, specimens were metallographically sectioned to examine the reaction product using light microscopy and scanning electron microscopy (SEM) equipped with energy dispersive X-ray spectroscopy (EDS). Oxide thickness was measured from SEM images using an image analysis tool developed at ORNL [12]. Five images of each specimen were used for this analysis, which resulted in more than 2000 measurements per specimen. 


\section{RESULTS}

\subsection{HYDROTHERMAL CORROSION}

Figure 2 compares the average mass change results for wrought and UAM Zry-4 after $500 \mathrm{~h}$ of hydrothermal corrosion at $330^{\circ} \mathrm{C}$. In both cases, the average mass gain was relatively low, $<0.25 \mathrm{mg} / \mathrm{cm}^{2}$. The three UAM specimens had a higher average mass gain and greater variability as indicated by the whiskers in Figure 2, which show one standard deviation. Macroscopic images of a typical UAM specimen before and after exposure in Figure 3 suggest that interlayer oxidation occurred. The wrought specimens had a uniform surface appearance after exposure. In cross-section, Figure 4a shows a backscattered electron (BSE) SEM image of an example of the interlayer oxidation where zirconium oxide has formed between layers near the edge of the sample. Occasionally larger internal separations were observed in these samples, as shown in Figure 4b. In the image, the separation does not appear to be connected to the surface but may be connected elsewhere, allowing internal oxidation to occur. Figure 5 shows representative images of the typical surface oxide formed on these specimens. Both the UAM and conventional Zry-4 specimens form similar, continuous, relatively uniform thickness scales under these conditions. Figure 6 shows box and whisker plots of the $\sim 2000$ measured oxide thicknesses for each specimen exposed. The median values are very similar for all of the specimens, ranging from 0.56-0.75 $\mu \mathrm{m}$. However, the whiskers indicate that occasional thicker areas were observed on the UAM specimens.

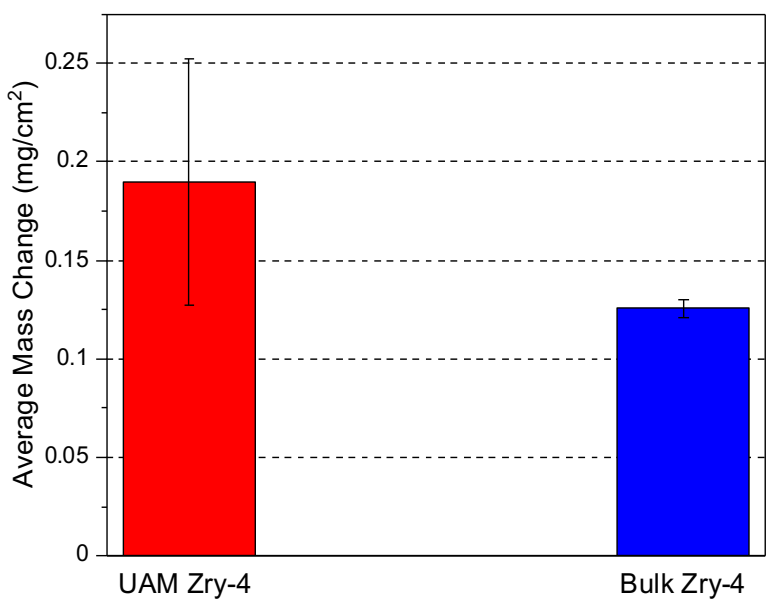

Figure 2. Mass change data for UAM and wrought Zry-4 tested in a continuously refreshing autoclave at $330^{\circ} \mathrm{C}, 15 \mathrm{MPa},<50 \mathrm{ppb}$ oxygen, for $500 \mathrm{~h}$. 

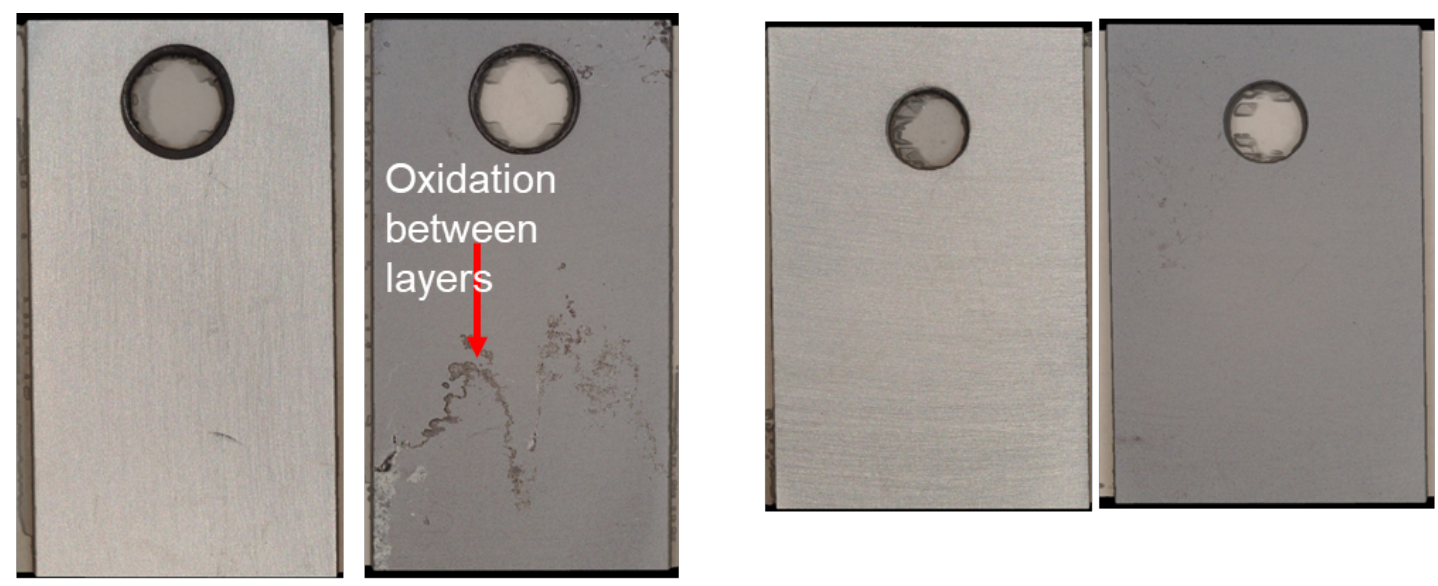

\section{UAM Before (L) and After (R) Bulk Before (L) and After (R)}

Figure 3. Optical images of representative samples from hydrothermal corrosion tests, exposed at $330^{\circ} \mathrm{C}, 15$ MPa, $<50$ ppb oxygen, for $500 \mathrm{~h}$.
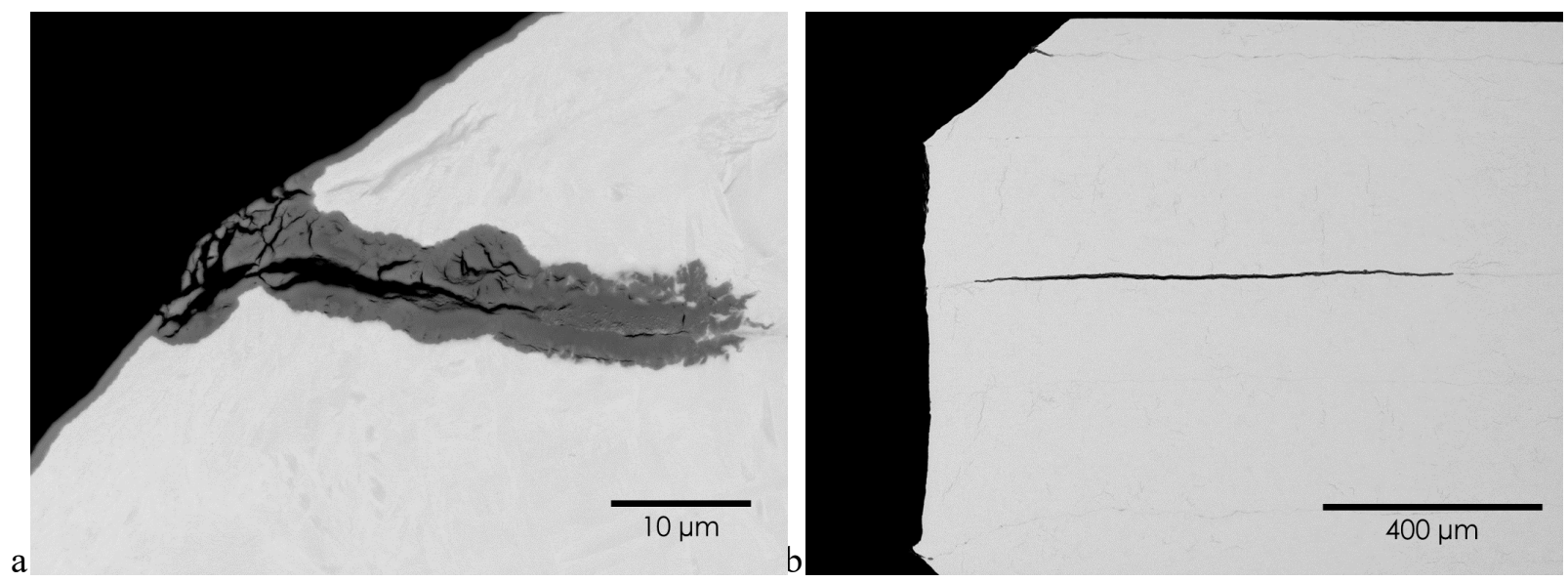

Figure 4. BSE SEM images of a UAM specimen after exposure in PWR conditions for $500 \mathrm{~h}$ at $330^{\circ} \mathrm{C}$
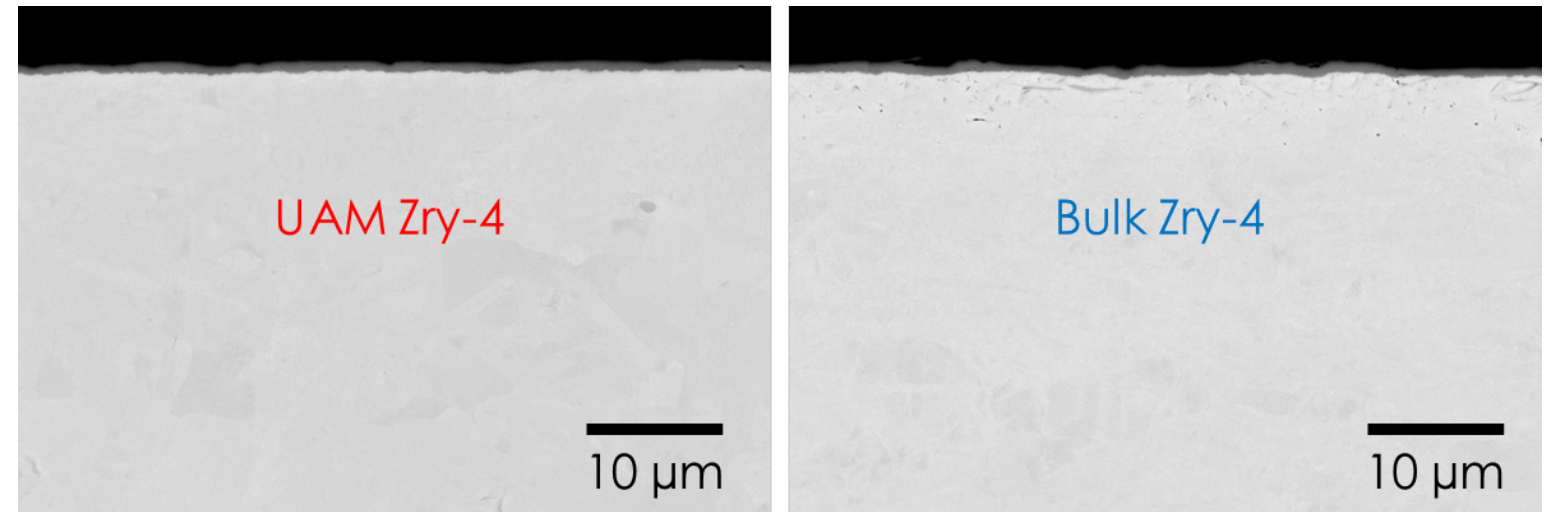

Figure 5. BSE SEM images of Zry-4 specimens after exposure in PWR conditions for $500 \mathrm{~h}$ at $330^{\circ} \mathrm{C}$, (a) UAM and (b) wrought 


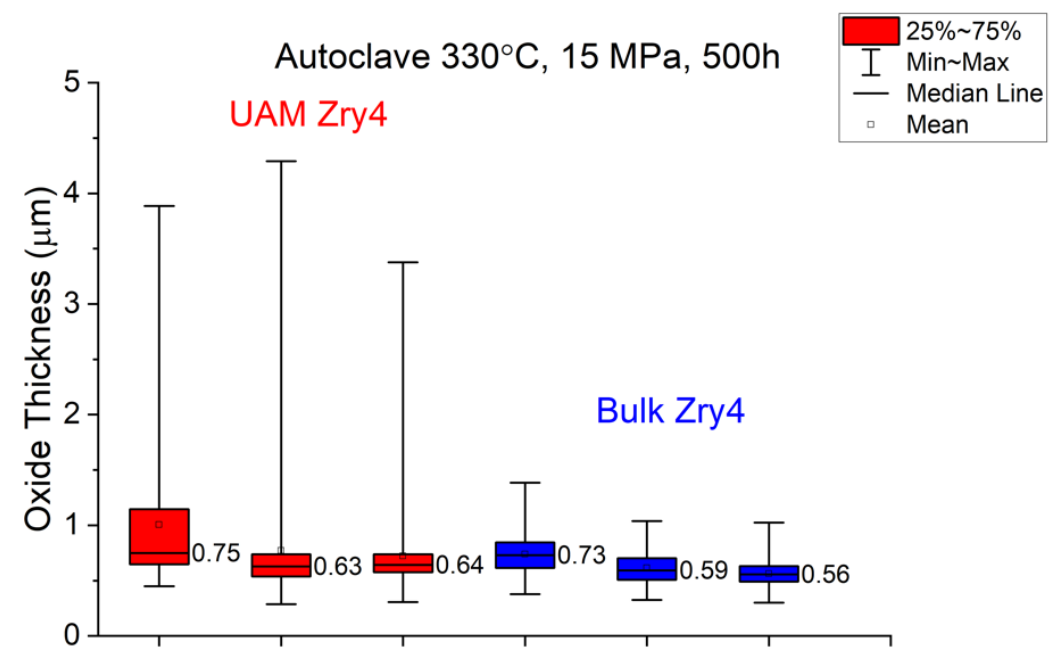

Figure 6. Oxide thickness measurements of each UAM and wrought Zry-4 samples tested in a continuously refreshing autoclave at $330^{\circ} \mathrm{C}, 15 \mathrm{MPa},<50 \mathrm{ppb}$ oxygen, for $500 \mathrm{~h}$. The boxes are defined by the $25 \%$ and $75 \%$ values and whiskers show the minimum and maximum values measured. Median oxide thicknesses are shown.

\subsection{STEAM EXPOSURES}

Mass change TGA data for samples exposed at $700^{\circ} \mathrm{C}$ in $100 \%$ steam are shown in Figure 7. Time and mass zero points were defined when the steam was introduced at $600^{\circ} \mathrm{C}$ and the shaded region is the time at $700^{\circ} \mathrm{C}$ with a ramp rate of $12^{\circ} \mathrm{C} / \mathrm{min}$. The mass changes in both cases were low with only a slightly higher mass gain for the UAM specimen. Similar to observations in hydrothermal corrosion, interlayer oxidation was observed in the UAM specimen, Figure 8. In this region, an area of increased oxidation occurred deep into the UAM specimen. The increase in volume due to the formation of $\mathrm{ZrO}_{2}$ likely caused the layers to further separate. In regions without internal oxidation, Figure 9 shows that the external $\mathrm{ZrO}_{2}$ scale was very similar on the UAM and wrought Zry-4 specimens. Thus, the higher mass gain observed in Figure 7 is likely due to interlayer oxidation.

Figure 10 shows mass change data for specimens tested in steam at $900^{\circ} \mathrm{C}$. As expected, the mass gains are approximately an order of magnitude higher than at $700^{\circ} \mathrm{C}$ with the UAM specimen again showing higher mass gain. In this case, substantial interlayer oxidation occurred causing the entire specimen to deform. Figure 11a shows the significant internal oxidation. The surface oxides on both sides of the specimen contained large cracks. Figure $11 \mathrm{~b}$ shows the more compact oxide formed on wrought Zry-4 after the same exposure. However, some cracks in the substrate can be seen beneath the scale. The cracking can be attributed to $\mathrm{O}$ and/or $\mathrm{H}$ ingress into the substrate and the associated embrittlement in the near surface region [13-15]. The difference in surface oxide thickness is quantified in Figure 12. The wrought Zry-4 specimen formed a much thinner and more uniform surface scale. The macroscopic specimen deformation due to the interlayer oxidation may have contributed to the accelerated growth of the surface oxide on the UAM specimen. 


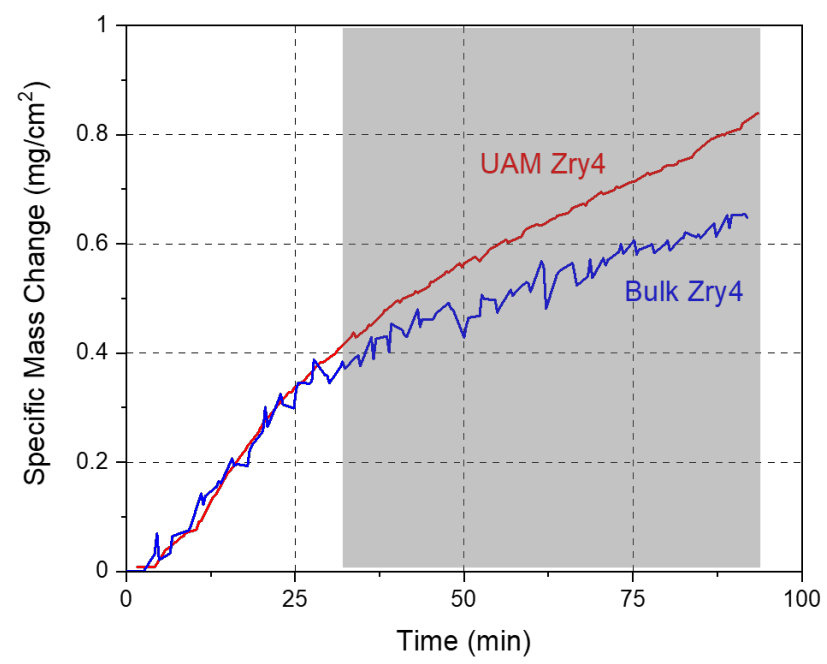

Figure 7. Specific mass change TGA data for UAM and wrought $\mathrm{Zry}-4$ tested in $100 \% \mathrm{H}_{2} \mathrm{O}(\mathrm{g})$ for $1 \mathrm{~h}$ at $700^{\circ} \mathrm{C}$. The shaded region shows the time at $700^{\circ} \mathrm{C}$ after steam was introduced at time zero.

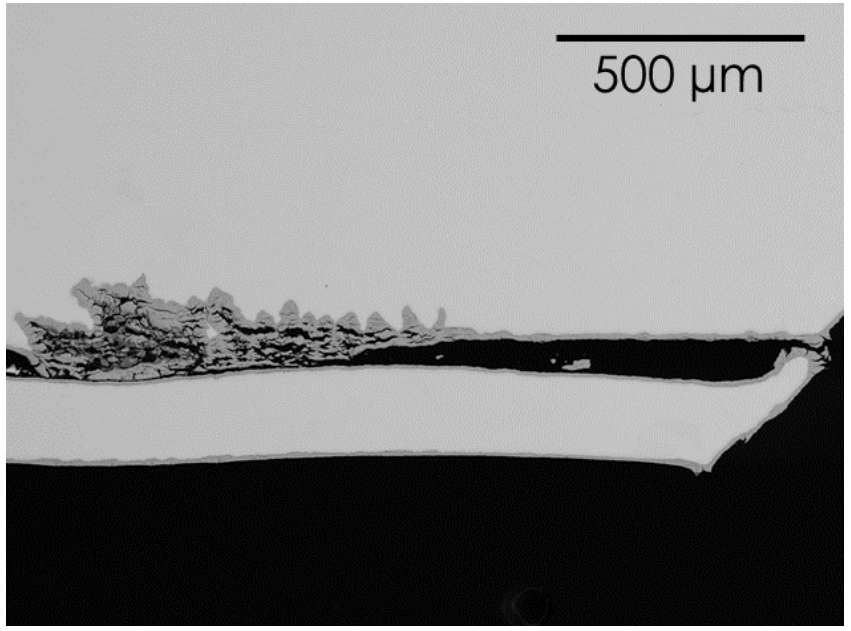

Figure 8. BSE SEM image of interlayer oxidation of a UAM Zry-4 sample tested in $100 \% \mathrm{H}_{2} \mathrm{O}(\mathrm{g})$ at $700^{\circ} \mathrm{C}$ for 1h. 


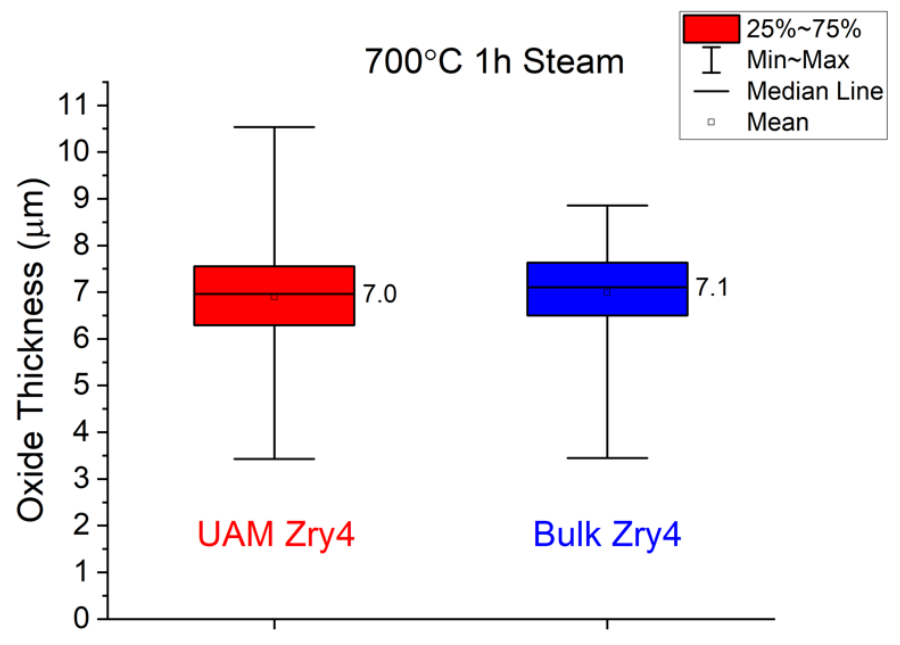

Figure 9. Oxide thickness measurements of the external oxide of UAM and wrought Zry-4 tested in 100\% $\mathrm{H}_{2} \mathrm{O}(\mathrm{g})$ at $700^{\circ} \mathrm{C}$ for $1 \mathrm{~h}$. No statistical difference exists.

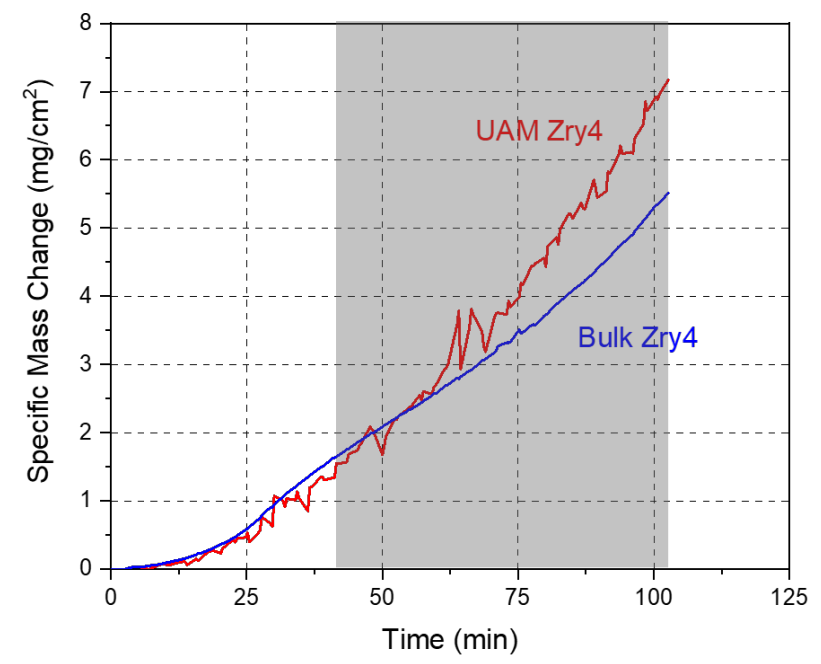

Figure 10. Specific mass change vs. time for UAM and wrought $\mathrm{Zry}-4$ tested in $100 \% \mathrm{H}_{2} \mathrm{O}$ at $900^{\circ} \mathrm{C}$ for 1h.The shaded region shows the time at $900^{\circ} \mathrm{C}$ after steam was introduced at $600^{\circ} \mathrm{C}$.
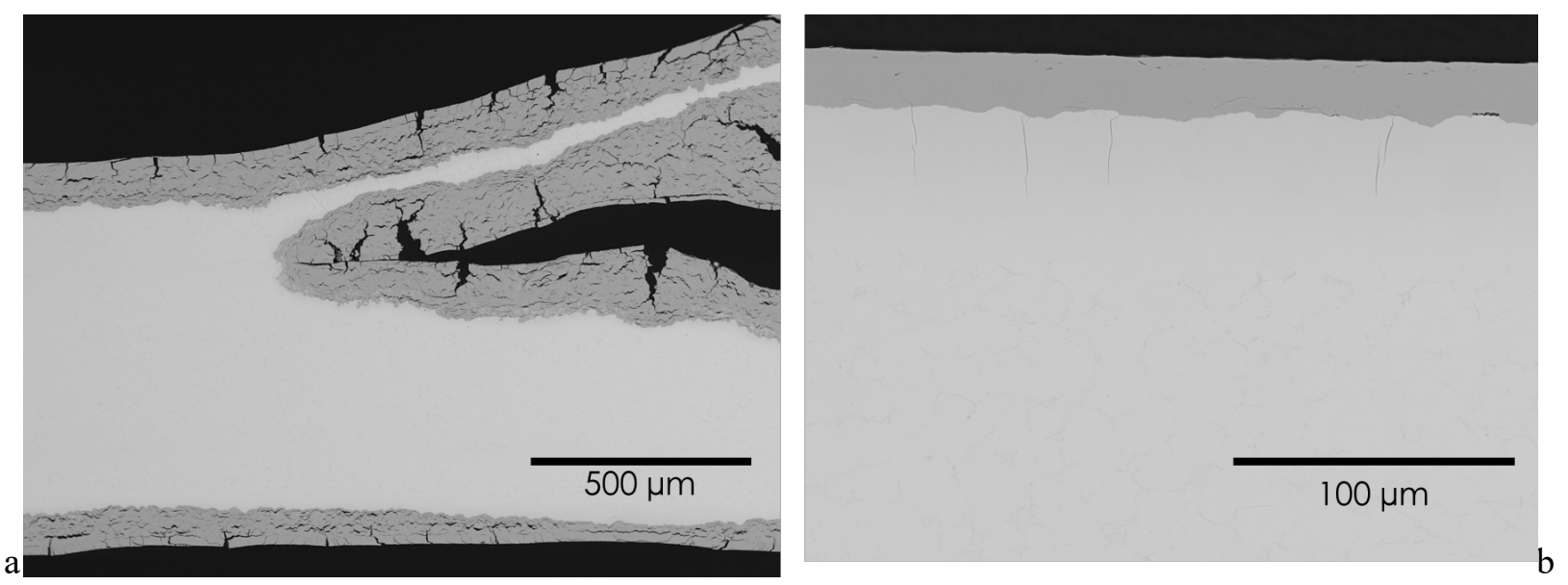

Figure 11. BES SEM images of Zry-4 after $1 \mathrm{~h}$ in steam at $900^{\circ} \mathrm{C}$, (a) UAM and (b) wrought. 


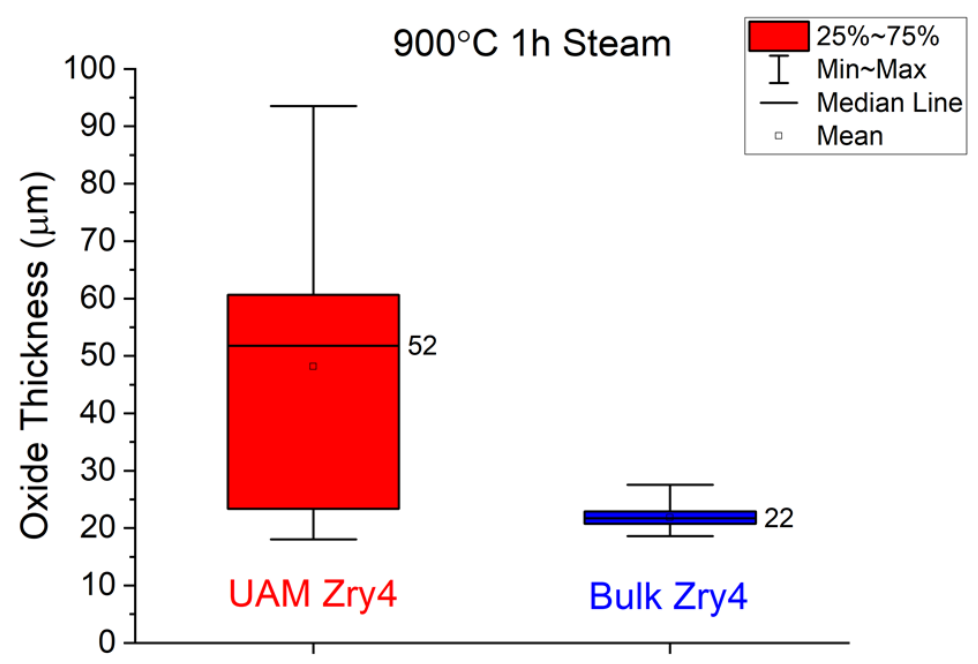

Figure 12. Oxide thickness measurements for UAM and wrought $\mathrm{Zry}-4$ tested in $100 \% \mathrm{H}_{2} \mathrm{O}$ at $900^{\circ} \mathrm{C}$ for $1 \mathrm{~h}$.

Figure 13 shows the mass change for specimens tested at $1100^{\circ} \mathrm{C}$ in steam with only a 10 min hold at temperature shown in the shaded area. Several wrought specimens were exposed and all showed much lower mass gain than the UAM specimen. Even with the shorter exposure time, the oxidation was so significant that the UAM specimen broke apart during cooling to room temperature and not all of the specimen was recovered. Figure 14 shows the more complex scale formed at this temperature. Multiple phases formed in the surface oxide on the UAM Zry-4 specimen. Characterization work is continuing to identify phases rich in Sn (red arrow in Figure 14a), Fe and Cr. Substrate cracks (circles in Figure 14) were larger after this exposure.

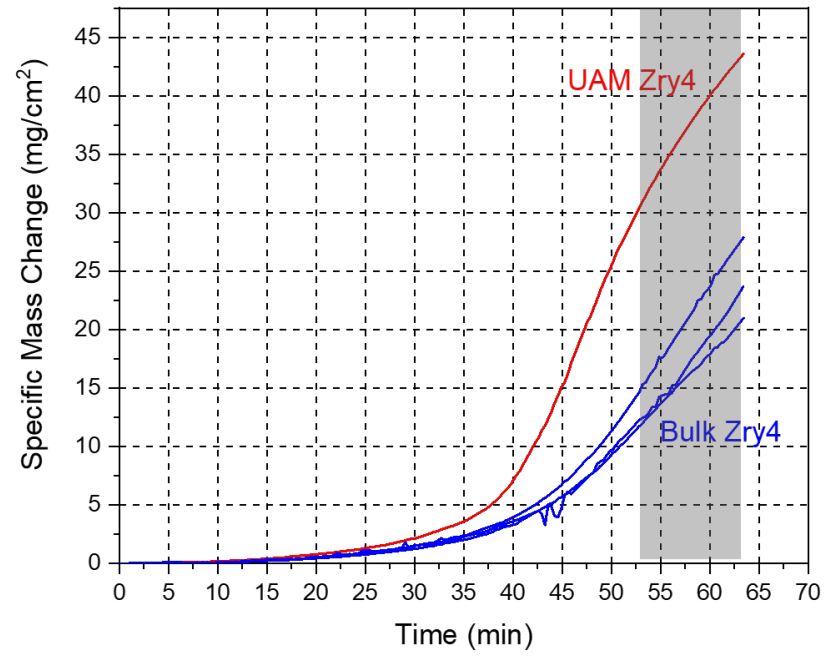

Figure 13. Mass change for UAM and wrought $\mathrm{Zry}-4$ samples tested in $100 \% \mathrm{H}_{2} \mathrm{O}(\mathrm{g})$ at $1100^{\circ} \mathrm{C}$ for $10 \mathrm{~min}$. The shaded region shows the time at $1100^{\circ} \mathrm{C}$. 

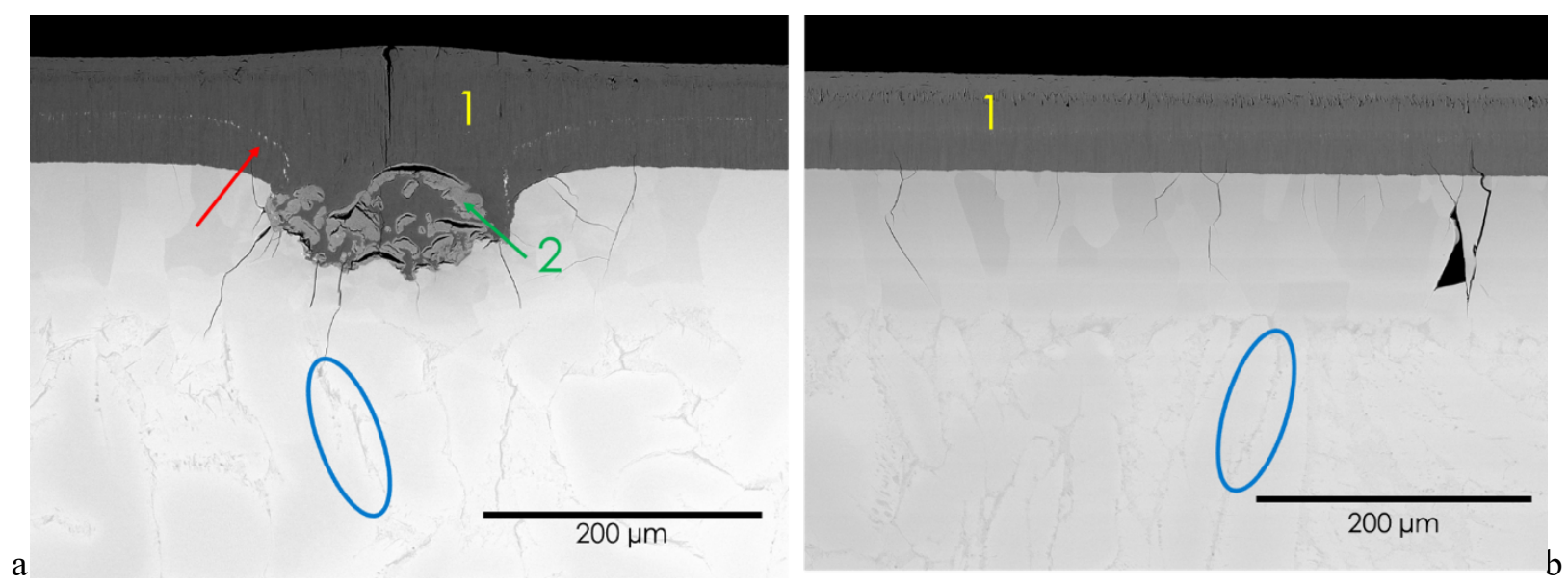

Figure 14. BSE SEM images of Zry-4 specimens (a) UAM and wrought Zry-4 samples exposed to $100 \%$ $\mathrm{H}_{2} \mathrm{O}(\mathrm{g})$ at $1100^{\circ} \mathrm{C}$ for $10 \mathrm{~min}$. The red arrow shows a $\mathrm{Sn}$ rich phase, 1 is the zirconium oxide scale, 2 is a $\mathrm{Zr}$ rich oxide phase, and the blue circle denotes areas of $\mathrm{Fe}$ and $\mathrm{Cr}$ segregation.

\section{CONCLUSIONS}

This initial evaluation of the oxidation behavior of Zry-4 made by ultrasonic additive manufacturing indicated that interlayer oxidation is a concern in both hydrothermal and steam oxidation conditions. In a simulation of normal LWR operating conditions, the surface oxides formed on UAM specimens were similar to those formed on conventional wrought Zry-4. Similar issues with accelerated oxidation at interlayers were observed in experiments to simulate accident scenarios using $100 \%$ steam at $700^{\circ}, 900^{\circ}$ and $1100^{\circ} \mathrm{C}$. Further process improvements may be needed to address the interlayer oxidation issue. Preexposure characterization of the UAM structure would be needed to determine the exact contribution of interlayer oxidation to the observed increase in mass change.

\section{ACKNOWLEDGMENTS}

This report is based upon work supported by the U.S. Department of Energy, National Nuclear Security Administration, Office of Defense Nuclear nonproliferation Research and Development. At ORNL, B. Johnston, A. Willoughby, S. Raiman and V. Cox assisted with the experimental work.

\section{REFERENCES}

1. P. Billot, P. Beslu, A. Giordano, J. Thomazet, "Development of a mechanistic model to assess the external corrosion of the zircaloy claddings in PWRs," in: Zirconium in the Nuclear Industry: Eighth International Symposium, 1989.

2. B. Cox, "Some thoughts on the mechanisms of in-reactor corrosion of zirconium alloys," J. Nucl. Mater. 336 (2005) 331-368.

3. T. Karlsen, C. Vitanza, Effects of pressurized water reactor (PWR) coolant chemistry on zircaloy corrosion behavior, in: Zirconium in the Nuclear Industry: Tenth International Symposium, 1994. 
4. C. P. Massey, C. J. Havrilak, M. N. Gussev, K. A. Terrani, A. T. Nelson, "Ultrasonic additive manufacturing of zirconium: Pilot results," Materials Letters, 302 (2021) 130330.

5. R.R. Dehoff, S.S. Babu, Characterization of interfacial microstructures in 3003 aluminum alloy blocks fabricated by ultrasonic additive manufacturing, Acta Materialia, 58 (2010) 4305-4315.

6. M.R. Sriraman, S.S. Babu, M. Short, Bonding characteristics during very high power ultrasonic additive manufacturing of copper, Scripta Materialia, 62(8) (2010) 560-563.

7. C.-H. Kuo, N. Sridharan, T. Han, M. J. Dapino and S. S. Babu, "Ultrasonic additive manufacturing of 4130 steel using Ni interlayers," Science and Technology of Welding and Joining, 24:5 (2019) 382-390.

8. A. Hehr, J. Wenning, K. Terrani, S.S. Babu and M. Norfolk, "Five-Axis Ultrasonic Additive Manufacturing for Nuclear Component Manufacture," JOM 69(3) (2016) 485.

9. R.E. Pawel, J.V. Cathcart, R.A. McKee, "The Kinetics of Oxidation of Zircaloy-4 in Steam at High Temperatures," Journal of The Electrochemical Society 126 (1979) 1105-1111.

10. M. Moalem and D.R. Olander, "Oxidation of Zircaloy by steam," Journal of Nuclear Materials 182 (1991) 170-194.

11. M. Steinbrück, N. Vér • M. Große, "Oxidation of Advanced Zirconium Cladding Alloys in Steam at Temperatures in the Range of $600-1200^{\circ} \mathrm{C}$," Oxidation of Metals 76 (2011) 215-232.

12. Y. F. Su, P. I. M. Stack, C. J. Stephens, K. A. Kane, S. Dryepondt, R. Pillai, B. A. Pint and B. M. Tossey, "Quantifying High Temperature Corrosion," NACE Paper C2021-16805, Houston, TX, presented virtually at NACE Corrosion 2021, April 2021.

13. S. J. Zinkle and G. S. Was, "Materials challenges in nuclear energy," Acta Materialia 61 (2013) 735-758.

14. M. S. El-Genk and J.-M. Tournier, "A review of refractory metal alloys and mechanically alloyed-oxide dispersion strengthened steels for space nuclear power systems," Journal of Nuclear Materials, 340 (2005) 93-112.

15. J. B. Bai, C. Prioul and D. Francois, "Hydride Embrittlement in ZIRCALOY-4 Plate: Part I. Influence of Microstructure on the Hydride Embrittlement in ZIRCALOY -4 at $20^{\circ} \mathrm{C}$ and $350^{\circ} \mathrm{C}$," Metallurgical Transactions A 25 (1994) 1185-1197. 